\title{
Concentration and Distribution of Inorganic Ions in Rainwater of Jos and Bukuru Metropolis, Plateau State, Nigeria
}

\author{
J. G. Nangbes ${ }^{* 1}$, B. M. Wufem*11, N. J. Shamle ${ }^{2}$ and J. B. Nvau ${ }^{1}$ \\ 1. Dept of Chemistry, Plateau State University, Bokkos, Nigeria ${ }^{2 \cdot}$ Dept. of Chemistry, University of Jos, \\ Plateau State, Nigeria
}

\begin{abstract}
Rainwater samples were collected during the raining season from five sites within Jos and Bukuru metropolis from April to October, 2002 and 2007. Eighty-five percent of the total rain events for the two years under study were sampled. The samples were analyzed using standard methods and results of the $\mathrm{pH}$ were attributed to increase in vehicle traffic within the study area. The concentration of the components $\mathrm{Cl}^{-}, \mathrm{NO}_{3}^{-}$, $\mathrm{NO}_{2}^{-}, \mathrm{SO}_{4}^{-}, \mathrm{PO}_{4}^{3-}, \mathrm{NH}_{4}^{+}, \mathrm{Na}^{+}, \mathrm{K}^{+}, \mathrm{Ca}^{2+}, \mathrm{Mg}^{2+}$ and $\mathrm{Cu}^{2+}$ were determined along with some other physical parameters. Colorimetric method was used to determine the concentration of the nonmetallic radicals while Atomic Absorption Spectrophotometry (AAS) was used to determine the concentration of the metals. Data obtained showed significant correlation of $\mathrm{SO}_{4}{ }^{2-}$ with $\mathrm{Cl}, \mathrm{NO}_{3}^{-}, \mathrm{NO}_{2}^{-}, \mathrm{SO}_{4}{ }^{2-}, \mathrm{PO}_{4}^{3-}, \mathrm{NH}_{4}^{+}, \mathrm{Na}^{+}, \mathrm{Mg}^{2+}$ and $\mathrm{Cu}^{2+}$. Also $\mathrm{NH}_{4}^{+}$correlated significantly with $\mathrm{Cl}^{-}, \mathrm{Na}^{+}, \mathrm{K}^{+}$, and $\mathrm{Ca}^{2+}$. These indicate the predominant anthropogenic sources, existence of aerosols such as $\left(\mathrm{NH}_{4}\right)_{2} \mathrm{SO}_{4}, \mathrm{NH}_{4} \mathrm{Cl}, \mathrm{NH}_{4} \mathrm{NO}_{3}$ and some other photochemical processes that occur below the cloud level. Data evaluated also reveal that local urban and industrial emission sources were primarily responsible for rainwater and atmospheric contamination which results in high ammonium and acidic $\mathrm{pH}$ concentrations. In this work, it was also revealed that increasing precipitation (rainfall amount) decreases the rainfall composition due to dilution and the deposition of rainfall composition is enhanced by high altitude of sites, with higher precipitation of ionic species between $15 \mathrm{~mm}$ and $35 \mathrm{~mm}$ of rainfall amount. The acidic nature of the rainwater indicates Jos and Bukuru metropolis rainwater to be hazardous for human consumption and may have adverse effect on human, plant, animal and material comfort.
\end{abstract}

Keywords: Health Hazard, Inorganic Ions, Pollutants, Rainwater.

\section{Introduction}

Rainwater gets its composition largely by dissolving particulate materials in the atmosphere (upper troposphere) when droplets of water nucleate on atmospheric particulate and secondarily by dissolving gases from the atmosphere. Rainwater composition varies geographically. Terrestrial rain composition varies significantly from place to place because the regional geology can greatly affect the types of particulates that get added to the atmosphere. When water droplets form and fall to earth, they pick up particles that float in the air. Similarly, sources of gaseous acids $\left(\mathrm{SO}_{3}, \mathrm{NO}_{3}\right)$ and bases $\left(\mathrm{NH}_{3}\right)$ vary as a function of biogenic factors and anthropogenic land use practices like construction work and agricultural activities. Each of these gases can be added in varying ways and proportions from natural and non-natural input sources. Particulate load to the atmosphere can also be greatly affected by human and natural activities. Finally local climate (especially the amount of precipitation in one area compared to another) will affect the solute concentrations in terrestrial rainwater. However, some air pollutants such as particulate matter, aerosols dust, soot, smoke and gases have effects on the quality of rainwater [1], [2]. Various works have been conducted on rainwater in different countries but virtually little or no work of this sort have been done in Nigeria, especially in Jos and Bukuru metropolis. Environmental researchers showed in their work on analysis of fog water in North India that the major constituents of fog water are $\mathrm{Ca}^{2+}, \mathrm{Na}^{+}, \mathrm{Mg}^{2+}$ and $\mathrm{K}^{+}$, which are released mostly from the soil. They also showed that other secondary ions like $\mathrm{SO}_{4}{ }^{2-}, \mathrm{NO}_{3}{ }^{-}$and $\mathrm{NH}_{4}{ }^{+}$are present but in lower concentrations [3]. Also, other researchers who have worked on rainwater found that $\mathrm{SO}_{4}{ }^{2-} \mathrm{NO}_{3}{ }^{-}$and $\mathrm{NH}_{4}{ }^{+}$are mostly from anthropogenic activities, released both directly and through photochemical conversion[4]. They also reported that the composition of rainwater is geographically distributed. The composition of rain water that reaches the earth surface is determined by the composition of aerosols and soluble gases in the cloud as well as in the air mass below the clouds. On the way down, rain droplets washout the air mass below the cloud base. These atmospheric materials could be carried to as far as $50,000 \mathrm{~km}$ by wind from point source and that most of the particulate matter is from anthropogenic sources [5]. Some other resent works also showed that solubility of aerosols, and particulate matters are $\mathrm{pH}$ - dependent, with a general increase in the dissolution rate of 
dissolved elements as the $\mathrm{pH}$ is lowered, but between $\mathrm{pH} 3.80$ and 5.30, the dissolution rate for $\mathrm{Fe}$ and $\mathrm{Cu}$ ions depended on both $\mathrm{H}^{+}$and $\mathrm{OH}^{-}$concentrations respectively [6] [7]. Major ions in marine rainwater with attention to sources of alkaline and acidic species were determined by ion chromatography, atomic absorption and colorimetric methods and the result showed that the major ions are $\mathrm{NH}_{4}^{+}, \mathrm{NO}_{3}{ }^{-}, \mathrm{SO}_{4}{ }^{2-}, \mathrm{Ca}^{2+}, \mathrm{Mg}^{2+}, \mathrm{K}^{+}, \mathrm{Na}^{+}$and $\mathrm{Cl}^{-}$[8]. In marine areas, the concentration of the major ions range over one or two orders of magnitude and are generally dominated by the redissolution in rainwater of sea salts. The non-sea salt (nss) component shows the presence of the anthropogenic nitric and sulphuric acids which are well correlated with the origin of the air masses which lead to acidic rain ( $\mathrm{pH} 4$ to 5). Nevertheless, high $\mathrm{pH}$ values ( $\mathrm{pH}$ 6-7) were also observed and this was attributed to the neutralization of strong acids by natural alkaline dust particles such as calcites, which are mainly transported from the desert areas of the Sahara region in Africa. Also, environmental literatures have reported that the major ions in a rainwater sample are $\mathrm{Cl}^{-}, \mathrm{NO}_{3}{ }^{-}, \mathrm{SO}_{4}^{2-}, \mathrm{Na}^{+}, \mathrm{K}^{+}, \mathrm{Mg}^{2+}, \mathrm{Ca}^{2+}, \mathrm{NH}_{4}^{+}$; having various concentration ranges [9]. They also reported that the major constituents of rainwater are smoke and fumes constituents from burning fossil fuels that rise into the atmosphere and combine with moisture in the air to form acid rain. The main chemicals in air pollution that create acid rain are sulphur dioxide and nitrogen oxides: Rainwater, snow, fog and other forms of precipitation containing mild solutions of sulphuric and nitric acids fall to the earth as acid rain. The constituents and sources of atmospheric aerosols and rainwater was also determined and reported to be mostly $\mathrm{Na}^{+}, \mathrm{Mg}^{2+}$ and $\mathrm{Cl}^{-}$predominantly from sea spray, soil, agriculture and industrial activities; $\mathrm{K}^{+}$, and $\mathrm{Ca}^{2+}$, predominantly soil- derived and agriculture; $\mathrm{H}^{+}$, from aqueous chemistry and strong acids; $\mathrm{NH}_{4}{ }^{+}$from ammonia neutralization of strong acids, agriculture, decay processes; and $\mathrm{SO}_{4}{ }^{2-}$, $\mathrm{NO}_{3}{ }^{-}$from oxidation of $\mathrm{SO}_{2}$ and $\mathrm{NO}_{2}$ respectively as a result of fossil burning, agriculture and sea spray [10]. In a related work, reports have it that the major ions in acid rain are $\mathrm{H}^{+}, \mathrm{K}^{+}, \mathrm{Na}^{+}, \mathrm{Ca}^{2+}, \mathrm{Mg}^{2+}, \mathrm{NH}_{4}^{+}, \mathrm{NO}_{3}^{-}$, and $\mathrm{NH}_{4}{ }^{+}$concentrations and high $\mathrm{SO}_{4}{ }^{2-}$ concentrations [11]. However $\mathrm{PO}_{4}{ }^{3-}$ was reported to be absent. The low concentrations of $\mathrm{NO}_{3}^{-}$, and $\mathrm{NH}_{4}{ }^{+}$, was attributed to low incidence of anthropogenic sources of these elements while high $\mathrm{SO}_{4}{ }^{2-}$, concentration was attributed to the effects of desert dust. It has also been published that biomass burning interferes a lot with the chemistry and composition of the atmosphere, which can also in turn alter the composition of rainwater. Biomass burning in the tropics is a major source of trace gases and aerosols, with wide ranging effects on atmospheric compositions [12]. Also deposition of compounds produced by biomass burning on pristine tropical ecosystems may affect their composition and dynamics. Forest fire also alters the long-term dynamics of the cycling and storage of elements within terrestrial ecosystem, thereby altering their significance as sources or sinks of various trace gases and also appears to have severe consequences on regional and global atmospheric chemistry and climate. It is common knowledge that residents of Jos and Bukuru metropolis prefer rainwater to pipe born, well or borehole waters for their consumption and domestic use they believe it is clean and pure. Rainwater collected and stored in rainwater tanks has been in use for a variety of non portable purposes for a long time by residents of these areas.

\section{Study Area}

Jos and Bukuru metropolis in Plateau State, Nigeria falls between Latitude $9^{\circ} 55^{\prime} 07^{\prime \prime} \mathrm{N}$ and Longitude $8^{\circ} 533^{\circ}$ "E, with good number of the residents relying on rainwater for their consumption and domestic use.

\section{Materials And Methods}

The rainwater samples were collected from five sites within Jos and Bukuru metropolis. These sites (Bukuru, Dadin Kowa, Industrial Area/Abattoir, Apata and Lamingo) were selected based on the different activities that ranged from industrial, domestic and agricultural. These sites were designated $S_{1}, S_{2}, S_{3}, S_{4}, S_{5}$ respectively for ease of identification. Samples were collected throughout the entire raining season of the years 2002 and 2007 from April to October of each year.

\section{Sampling Technique And Sample Handling}

Sampling was done mainly as described in other related works [4], [9], [13], [14]. The sample collected was then immediately taken to the laboratory for weighing and the measurement of $\mathrm{pH}$ and conductivity. In this way too the volume collected was known. In the case where this was not possible (e.g. midnight storm), the sample collected was stored in the refrigerator at $4^{\circ} \mathrm{C}$ till daybreak and then taken to the laboratory for reweighing, $\mathrm{pH}$ and conductivity measurements. An average of fifty rain events was recorded in each of the five study sites, beginning from $8^{\text {th }}$ April to $17^{\text {th }}$ October 2002 and fifty-five rain events, beginning from $7^{\text {th }}$ April to $22^{\text {nd }}$ October, 2007. A total of thirty-nine rain samples from these rain events were collected each year. The samples were then serially numbered according to rain events. UV-Visible Spectrophotomtric method was used for the determination of anions [9], while flame atomic absorption spectroscopy (FAAS) was 
used for the determination of $\mathrm{K}, \mathrm{Ca}, \mathrm{Mg}$ and $\mathrm{Cu}$ in the rainwater samples [13], [14], [15]. For total acidity and hardness, titrimetric method was used for their determination [16], [17]. For the determination of chloride ion, the argentometric method was used [16] while gravimetric method was used for the determination of total and dissolved solids. Suspended solids were obtained by difference [9].

\section{Results And Discussion}

Mean results of the examination of the physicochemical parameters in the rainfall water composition are as shown in Table I alongside WHO drinking water quality standards for comparison [18]. Tables II and III provide the calculated average volume weighted mean $(\mathrm{vwm})(\mathrm{mg} / \mathrm{l})$ and average deposition rate of chemical parameters $(\mathrm{mg} . \mathrm{cm} / \mathrm{h})$ respectively [9].

\begin{tabular}{|c|c|c|c|c|c|c|}
\hline \multirow[t]{2}{*}{ PARAMETERS } & \multicolumn{6}{|c|}{ MEAN CONCENTRATION (mg/L) } \\
\hline & $\mathrm{S}_{1}$ & $\mathrm{~S}_{2}$ & $\mathrm{~S}_{3}$ & $\mathrm{~S}_{4}$ & $\mathrm{~S}_{5}$ & WHO STD \\
\hline $\begin{array}{l}\text { Conductivity } \\
(\mu \mathrm{scm} 1)\end{array}$ & $\begin{array}{ll}48.14 & \pm \\
0.73 & \end{array}$ & $\begin{array}{ll}47.69 \quad \pm \\
1.58 & \end{array}$ & $\begin{array}{ll}47.40 \quad \pm \\
1.83\end{array}$ & $\begin{array}{ll}46.95 & \pm \\
1.44 & \end{array}$ & $\begin{array}{ll}48.23 \quad \pm \\
0.64 & \end{array}$ & 400 \\
\hline Colour (Hazen) & $2.01 \pm 1.15$ & $\begin{array}{ll}2.43 & \pm \\
1.12 & \end{array}$ & $\begin{array}{ll}2.79 & \pm \\
1.75 & \end{array}$ & $1.45 \pm 1.10$ & $0.90 \pm 0.81$ & 5 \\
\hline Turbidity (FTU) & $0.60 \pm 039$ & $\begin{array}{ll}0.79 & \pm \\
0.36 & \\
\end{array}$ & $\begin{array}{ll}0.90 & \pm \\
0.57 & \end{array}$ & $0.76 \pm 0.34$ & $0.64 \pm 0.26$ & 5 \\
\hline $\begin{array}{l}\begin{array}{l}\text { Suspended } \\
(\mathrm{mg} / \mathrm{L})\end{array} \\
\text { solid }\end{array}$ & $18.84 \pm 5.57$ & $\begin{array}{ll}16.19 \quad \pm \\
3.19 & \end{array}$ & $\begin{array}{ll}30.42 & \pm \\
19.48 & \end{array}$ & $\begin{array}{ll}18.98 \quad \pm \\
9.96 & \end{array}$ & $\begin{array}{l}16.43 \\
2.97\end{array}$ & 500 \\
\hline $\begin{array}{l}\text { Total dissolved } \\
\text { solids }(\mathrm{mg} / \mathrm{L})\end{array}$ & $\begin{array}{l}50.49 \\
18.67\end{array}$ & $\begin{array}{l}52.69 \\
\pm 22.87\end{array}$ & $\begin{array}{ll}75.48 & \pm \\
22.76 & \end{array}$ & $\begin{array}{l}67.93 \\
28.32\end{array}$ & $\begin{array}{l}52.47 \\
9.78\end{array}$ & 500 \\
\hline Total solids (mg/L) & $\begin{array}{l}69.33 \\
23.01\end{array}$ & $\begin{array}{ll}68.86 & \pm \\
24.11 & \end{array}$ & $\begin{array}{l}105.79 \pm \\
37.40\end{array}$ & $\begin{array}{l}86.92 \\
33.12\end{array}$ & $\begin{array}{ll}68.90 & \pm \\
9.09 & \end{array}$ & 1000 \\
\hline Odour/Smell/Taste & $\begin{array}{l}\text { Non } \\
\text { objectionabl } \\
\text { e }\end{array}$ & $\begin{array}{l}\text { Non } \\
\text { objectiona } \\
\text { ble }\end{array}$ & $\begin{array}{l}\text { Non } \\
\text { objectiona } \\
\text { ble }\end{array}$ & $\begin{array}{l}\text { Non } \\
\text { objectionabl } \\
\text { e }\end{array}$ & $\begin{array}{l}\text { Non } \\
\text { objectionabl } \\
\text { e }\end{array}$ & $\begin{array}{l}\text { Non } \\
\text { objectionabl } \\
\text { e }\end{array}$ \\
\hline $\begin{array}{ll}\text { Total } & \text { acidity } \\
\left(\mathrm{CaCO}_{3}\right) & \end{array}$ & $1.12 \pm 0.53$ & $\begin{array}{ll}1.03 & \pm \\
0.55 & \end{array}$ & $\begin{array}{ll}1.10 & \pm \\
0.51 & \end{array}$ & $1.74 \pm 1.21$ & $0.91 \pm 0.36$ & - \\
\hline Hardness $\left(\mathrm{CaCO}_{3}\right)$ & $10.79 \pm 1.03$ & $\begin{array}{ll}10.38 & \pm \\
1.22 & \end{array}$ & $\begin{array}{l}10.63 \\
1.59\end{array}$ & $\begin{array}{ll}11.69 \quad \pm \\
1.33 & \end{array}$ & $\begin{array}{ll} & 11.41 \quad \pm \\
0.62 & \end{array}$ & 60.00 \\
\hline $\mathrm{pH}$ & $6.29 \pm 0.49$ & $\begin{array}{ll}6.03 & \pm \\
0.33 & \\
\end{array}$ & $\begin{array}{ll}6.05 & \pm \\
0.26 & \\
\end{array}$ & $6.10 \pm 0.61$ & $6.29 \pm 0.56$ & $6.5-8.5$ \\
\hline Ammonium $\left(\mathrm{NH}_{4}^{+}\right)$ & $\begin{array}{l}0.95 \pm 0.69 \\
\text { (a) }\end{array}$ & $\begin{array}{l}0.61 \\
0.38\end{array}$ & $\begin{array}{l}0.18 \\
0.17\end{array}$ & $\begin{array}{lrr}0 . & 90 & \pm \\
0.59(\mathrm{a}) & \\
\end{array}$ & $\begin{array}{ll}0.95 & \pm \\
0.61(\mathrm{a}) & \\
\end{array}$ & 0.50 \\
\hline Chloride $\left(\mathrm{Cl}^{-}\right)$ & $4.16 \pm 1.18$ & $\begin{array}{l}3.83 \pm \\
1.42\end{array}$ & $\begin{array}{l}3.69 \\
0.60\end{array}$ & $4.20 \pm 1.01$ & $3.66 \pm 0.66$ & 250.00 \\
\hline Sulphate $\left(\mathrm{SO}_{4}{ }^{2-}\right)$ & $4.14 \pm 2.02$ & $\begin{array}{ll}3.22 \quad \pm \\
2.05 & \end{array}$ & $\begin{array}{l}7.25 \\
6.27\end{array}$ & $5.31 \pm 2.09$ & $7.83 \pm 5.94$ & 250.00 \\
\hline Nitrate $\left(\mathrm{NO}_{3}{ }^{-}\right)$ & $\begin{array}{l}2.82 \pm 2.38 \\
\text { (b) }\end{array}$ & $\begin{array}{ll}1.90 & \pm \\
1.33 & \end{array}$ & $\begin{array}{l}0.64 \\
0.60\end{array}$ & $\begin{array}{l}1.46 \pm 1.31 \\
\text { (b) }\end{array}$ & $\begin{array}{l}2.83 \pm 1.97 \\
\text { (b) }\end{array}$ & 50.00 \\
\hline Phosphate $\left(\mathrm{PO}_{4}{ }^{3-}\right)$ & $3.29 \times 10^{-3}$ & $2.88 \times 10^{-}$ & $\begin{array}{ll}0.043 \quad \pm \\
0.048 & \end{array}$ & $\begin{array}{l}3.83 \times 10^{-3} \\
(\mathrm{C})\end{array}$ & $\begin{array}{l}3.83 \times 10^{-3} \\
(\mathrm{C})\end{array}$ & 0.30 \\
\hline Nitrite $\left(\mathrm{NO}_{2}^{-}\right)$ & $\begin{array}{l}1.91 \pm 1.56 \\
(\mathrm{C})\end{array}$ & $\begin{array}{l}1.40 \\
1.27\end{array}$ & $\begin{array}{ll}0.49 & \pm \\
0.44 & \end{array}$ & $0.82 \pm 0.84$ & $2.31 \pm 1.63$ & 3.00 \\
\hline Sodium $\left(\mathrm{Na}^{+}\right)$ & $\begin{array}{l}4.712 \quad \pm \\
0.336\end{array}$ & $\begin{array}{l}4.828 \\
1.808\end{array}$ & $\begin{array}{l}6.569 \\
\pm 2.087\end{array}$ & $\begin{array}{l}6.205 \\
2.868\end{array}$ & $\begin{array}{l}4.437 \\
0.153\end{array}$ & 200.00 \\
\hline Potassium $\left(\mathrm{K}^{+}\right)$ & $\begin{array}{l}0.409 \\
0.125\end{array}$ & $\begin{array}{ll}0.394 \quad \pm \\
212 & \\
\end{array}$ & $\begin{array}{ll}0.413 \quad \pm \\
0.265 & \end{array}$ & $\begin{array}{l}0.680 \\
\pm 0.198(\mathrm{~d})\end{array}$ & $\begin{array}{l}0.319 \\
0.198\end{array}$ & 75.00 \\
\hline Calcium $\left(\mathrm{Ca}^{2+}\right)$ & $\begin{array}{l}4.383 \\
0.677\end{array}$ & $\begin{array}{l}4.026 \\
0.477\end{array}$ & $\begin{array}{ll}4.165 \quad \pm \\
0.812\end{array}$ & $\begin{array}{ll}4.709 & \pm \\
0.731 & \\
\end{array}$ & $\begin{array}{l}4.347 \\
0.536\end{array}$ & 75.00 \\
\hline Magnesium $\left(\mathrm{Mg}^{2+}\right)$ & $\begin{array}{l}0.059 \\
0.025\end{array}$ & $\begin{array}{l}0.106 \\
0.162\end{array}$ & $\begin{array}{l}0.082 \\
0.076\end{array}$ & $\begin{array}{l}0.064 \\
0.014\end{array}$ & $\begin{array}{l}0.137 \\
0.241\end{array}$ & 50.00 \\
\hline Copper $\left(\mathrm{Cu}^{2+}\right)$ & $\begin{array}{l}0.386 \\
0.120\end{array}$ & $\begin{array}{l}0.489 \\
0.219\end{array}$ & $\begin{array}{ll}0.635 & \pm \\
0.481 & \end{array}$ & $\begin{array}{l}0.802 \\
0.621\end{array}$ & $\begin{array}{l}0.404 \\
0.194\end{array}$ & 1.00 \\
\hline $\begin{array}{l}\text { Ratio } \\
\Sigma \text { Cation) } \\
\Sigma \text { Anions }\end{array}$ & 1.17 & 1.08 & 1.15 & 1.25 & 0.70 & \\
\hline
\end{tabular}

TABLE I: Physicochemical Parameters (of rainwater samples in Jos and Bukuru of Plateau state,Nigeria).

$\mathrm{S}_{1}$. Rainfall water samples from Bukuru site

$\mathrm{S}_{2}$. Rainfall water samples from Dadin kowa site

$\mathrm{S}_{3}$. Rainfall water samples from Abattoir/Industrial Area site

$\mathrm{S}_{4}$. Rainfall water samples from Apata site

$\mathrm{S}_{5}$. Rainfall water samples from Lamingo site 


\begin{tabular}{|l|l|l|l|l|l|}
\hline Parameter & $\mathrm{S}_{1}$ & $\mathrm{~S}_{2}$ & $\mathrm{~S}_{3}$ & $\mathrm{~S}_{4}$ & $\mathrm{~S}_{5}$ \\
\hline Total Acidity & 1.28 & 1.07 & 1.11 & 1.84 & 0.86 \\
\hline Total Hardness & 10.53 & 9.97 & 10.44 & 11.67 & 11.70 \\
\hline $\mathrm{pH}$ & 6.22 & 6.14 & 6.02 & 6.09 & 5.99 \\
\hline Ammonium & 0.79 & 0.48 & 0.18 & 0.92 & 0.68 \\
\hline Chloride & 4.17 & 4.23 & 3.68 & 4.12 & 3.30 \\
\hline Sulphate & 3.97 & 2.84 & 6.14 & 5.11 & 10.95 \\
\hline Nitrate & 2.41 & 1.45 & 0.61 & 1.39 & 2.01 \\
\hline Phosphate & $5.54 \times 10^{-3}$ & $6.76 \times 10^{-3}$ & 0.033 & $4.04 \times 10^{-3}$ & $9.81 \times 10^{-3}$ \\
\hline Nitrite & 1.66 & 1.00 & 0.46 & 0.84 & 1.66 \\
\hline Sodium & 4.765 & 5.794 & 6.302 & 6.055 & 4.355 \\
\hline Potassium & 0.382 & 0.426 & 0.453 & 0.684 & 0.409 \\
\hline Calcium & 4.314 & 3.976 & 4.089 & 4.652 & 4.520 \\
\hline Magnesium & 0.055 & 0.063 & 0.084 & 0.066 & 0.129 \\
\hline Copper & 0.382 & 0.500 & 0.639 & 0.782 & 0.288 \\
\hline
\end{tabular}

Table II: Average volume weighted mean (VWM) of chemical parameters (mg/L).

\begin{tabular}{|l|l|l|l|l|l|}
\hline Parameter & $\mathrm{S}_{1}$ & $\mathrm{~S}_{2}$ & $\mathrm{~S}_{3}$ & $\mathrm{~S}_{4}$ & $\mathrm{~S}_{5}$ \\
\hline Total Acidity & 5.73 & 3.71 & 3.31 & 3.42 & 2.94 \\
\hline $\begin{array}{l}\text { Total } \\
\text { Hardness }\end{array}$ & 46.49 & 30.79 & 29.70 & 20.84 & 39.93 \\
\hline $\mathrm{pH}$ & 5.78 & 5.61 & 5.64 & 5.87 & 5.83 \\
\hline Ammonium & 2.12 & 1.38 & 0.50 & 1.45 & 2.40 \\
\hline Chloride & 16.95 & 12.26 & 11.36 & 7.31 & 11.39 \\
\hline Sulphate & 16.30 & 10.50 & 17.59 & 8.51 & 34.36 \\
\hline Nitrate & 7.42 & 4.75 & 1.68 & 2.15 & 7.48 \\
\hline Phosphate & 0.17 & 0.15 & 0.11 & 0.06 & 0.16 \\
\hline Nitrite & 4.86 & 2.87 & 1.27 & 1.37 & 5.72 \\
\hline Sodium & 23.92 & 17.31 & 17.61 & 11.18 & 14.97 \\
\hline Potassium & 1.94 & 1.24 & 1.15 & 1.18 & 1.41 \\
\hline Calcium & 21.09 & 10.89 & 10.24 & 8.28 & 15.72 \\
\hline Magnesium & 0.21 & 0.22 & 0.23 & 0.11 & 0.65 \\
\hline Copper & 1.50 & 1.51 & 1.59 & 1.38 & 1.06 \\
\hline
\end{tabular}

Table III: Average Deposition rate of Chemical parameter (mg.cm/h)

\section{Test of Significance of Mean}

The data (chemical and physical) was evaluated using statistical methods to test for the significance of the means for each parameter for different sites using the $t$ - test, at 95\% confidence level [19], [20]. The mean difference is significant if the calculated value is greater than the tabulated value, and is not significant if it is less than the tabulated value. Also, a statistical program, Statistical Package for Social Scientist (SPSS version 11.00) was used to the tests. These tests of significance revealed that the mean of the chemical parameters was not significant among all sites except for $\mathrm{NH}_{4}{ }^{+}, \mathrm{NO}_{2}{ }^{-}, \mathrm{NO}_{3}{ }^{-}$and $\mathrm{K}^{+}$. The mean concentration of $\mathrm{NH}_{4}{ }^{+}$at Bukuru was significant to that at Lamingo and Apata. Also, mean $\mathrm{K}^{+}$concentration at Apata was significant to that of all the other sites. The mean concentrations of the physical parameters showed some significant differences among the sites only in total, dissolved and suspended solids, at $95 \%$ confidence level, these parameters showed significant difference in the mean concentration. There is significant difference in the means of $\mathrm{S}_{1}$, to that of $S_{3} ; S_{2}$ to that of $S_{3} ; S_{3}$ to that of $S_{2}$ and $S_{5}$. Also mean between parameters, were compared at $95 \%$ confidence level and it was found not to be significant for $\mathrm{Cl}^{-}$and $\mathrm{Na}^{+} ; \mathrm{NO}_{3}{ }^{-}, \mathrm{NO}_{2}{ }^{-}$and acidity; $\mathrm{PO}_{4}{ }^{3-}$ and $\mathrm{K}^{+}$; $\mathrm{Na}^{+}$and $\mathrm{K}^{+} ; \mathrm{Mg}^{2+}, \mathrm{K}^{+}$and $\mathrm{Cu}^{2+} \mathrm{NH}_{3}^{+}$and $\mathrm{Mg}^{2+}, \mathrm{Cu}^{2+}, \mathrm{K}^{+}, \mathrm{PO}_{4}{ }^{3-}$.

\section{Pearson Correlation}

A Pearson correlation coefficient of each pair of chemical ionic species was computed and correlation matrix prepared, using SPSS Statistical Software Version 11.00. This was with the view of establishing the existence of these ions in their natural compound form as they are in the atmospheric aerosols [3], [4], [11], [13], [21]. The correlation matrix also helps to give a clue of the sources of these chemical species and the sources of their components [22], [23].

\section{Scatter Plots of Ionic Species}

A concentration versus rainfall amount (mmRain) of each of the ionic species determined in all the rainwater samples collected was plotted to give the scatter plots (Figs. $1-6$ ), which give a pictorial dispersion of the ionic species in the atmosphere and the rainwater precipitate. 
Fig. 1: Scatter plots of $\left[\mathrm{SO}_{4}{ }^{2-}\right] \&[\mathrm{Cl}]$ versus mm Rain
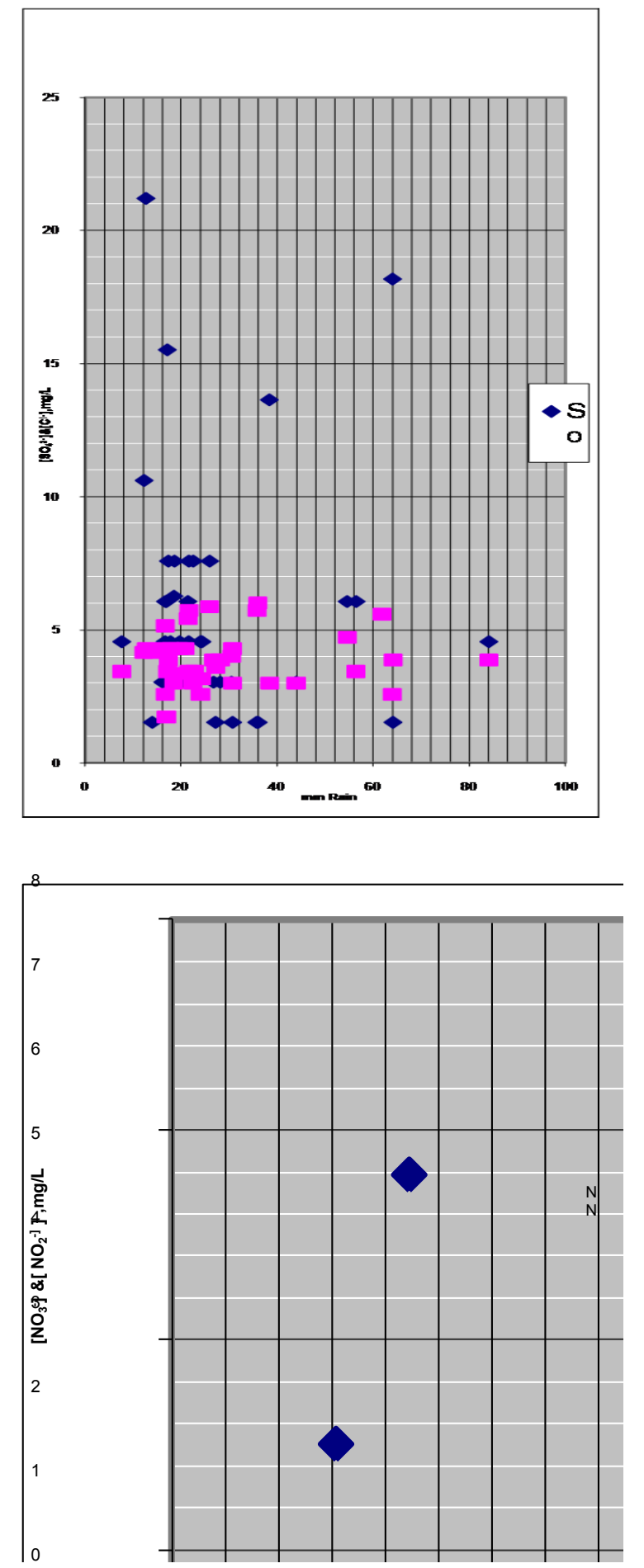

Fig. 2: Scatter plots of $\left[\mathrm{NO}_{3}^{-}\right] \&\left[\mathrm{NO}_{2}{ }^{-}\right]$versus mm Rain 


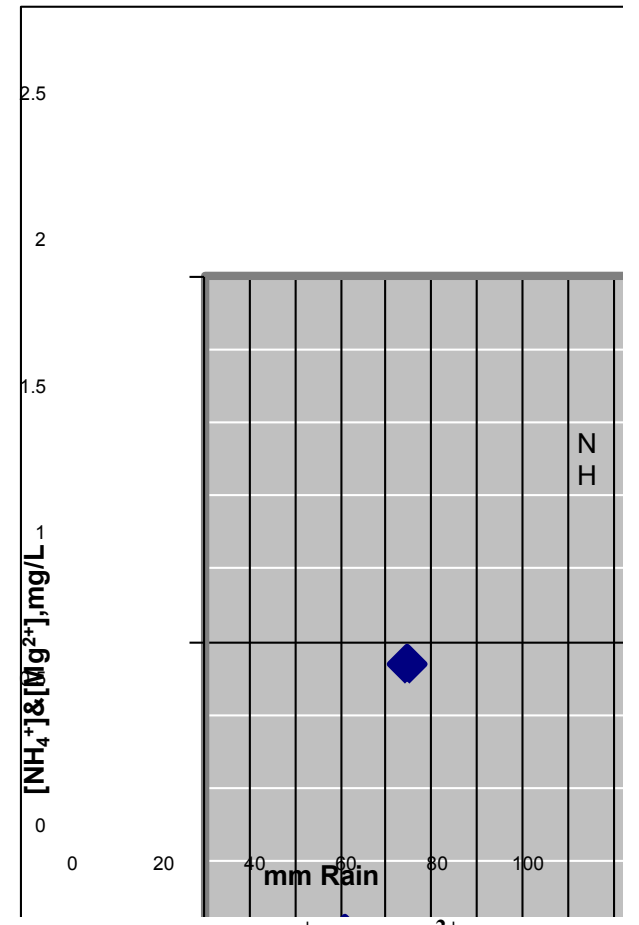

Fig. 3: Scatter plots of $\left[\mathrm{NH}_{4}^{+}\right] \&\left[\mathrm{Mg}^{2+}\right]$ versus mm Rain

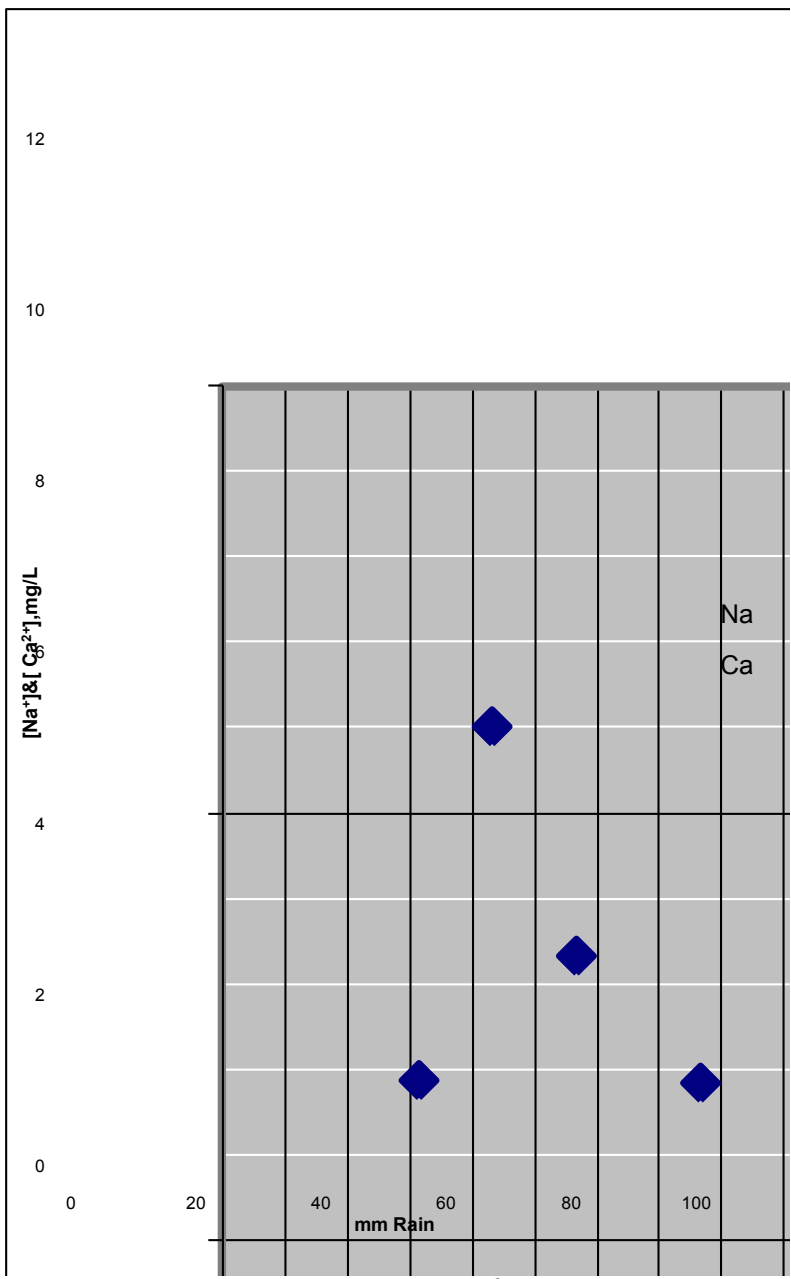

Fig. 4: Scatter plots of $\left[\mathrm{Na}^{+}\right] \&\left[\mathrm{Ca}^{2+}\right]$ Versus mm Rain 


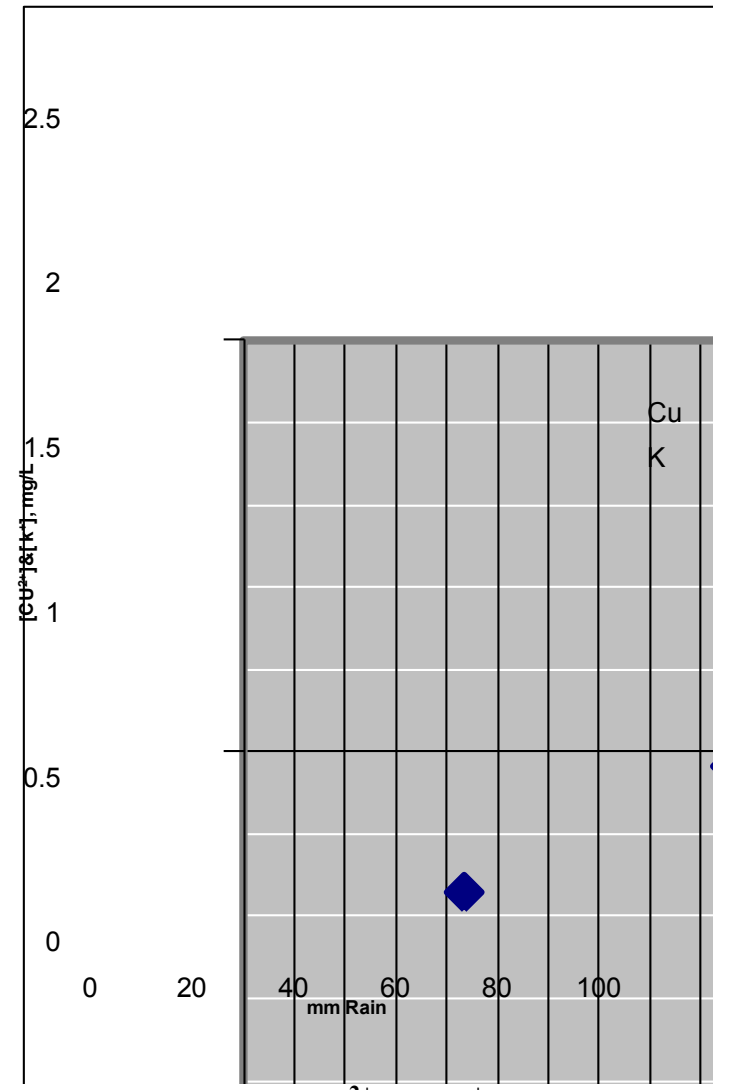

Fig. 5: Scatter plots of $\left[\mathrm{Cu}^{2+}\right] \&\left[\mathrm{~K}^{+}\right]$versus mm Rain

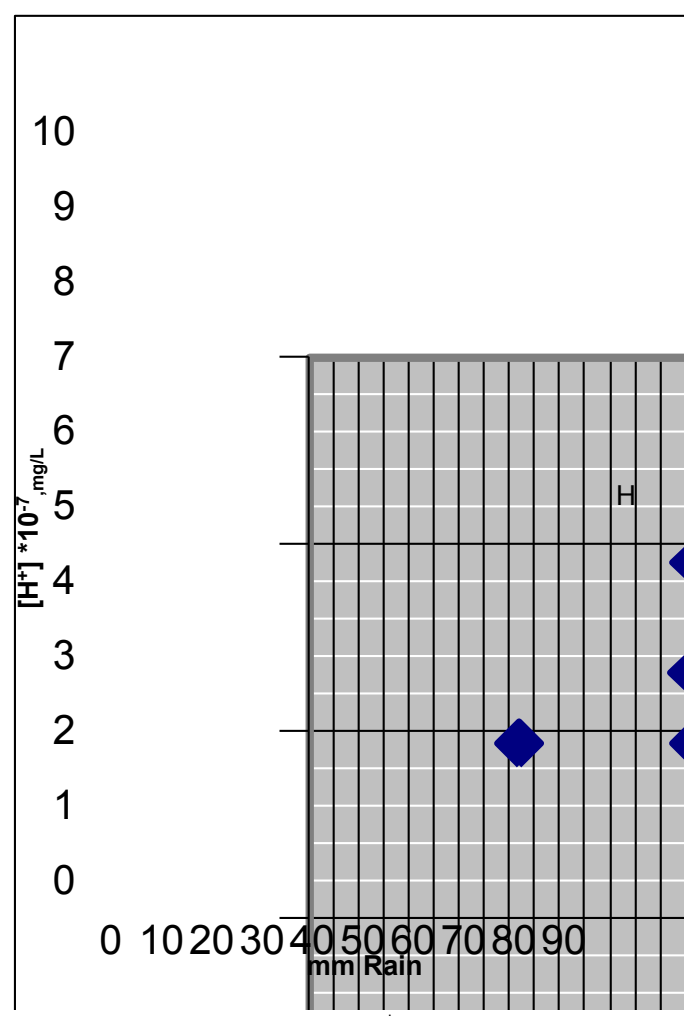

Fig. 6: Scatter plots of $\left[\mathrm{H}^{+}\right]$versus mm Rain 


\section{Discussion}

In the chemical parameters, the summation of the ratio of cations to anions is expected to be unity if all the species in the rain samples were analyzed correctly [3], [9]. A slight variation of this as indicated in the results could be attributed to the fact that not all of neither the cations nor anions in the rainwater samples have probably been completely analyzed. Examples of such are the bicarbonates, lead, zinc, aluminum, acetic acid, Barium, silver, silica, pesticides, arsenic, and cyanide. It is likely these species could exist in appreciable concentrations. However, the ratio obtained for all the five sites is approximately unity (Table 1). This implies that the results of the chemical parameters are correct as reported and also that the major ions in the rainwater samples are the ones being analyzed as reported in other similar works [3], [9], [11], [21].

\section{Physical Parameters}

The highest colour result is in $S_{3}$ with value $2.79 \pm 1.75$. This value could be attributed to industrial and human activities taking place at that region, most especially at the Abattoir market where skins and hides, and bone are burnt in large quantities every day, resulting in the accumulation of soluble and insoluble organic compounds. Colouration in rainwater could also be as a result of oxidation of dissolved metals and other inorganic compounds by the atmospheric process like thunderstorm. Conductivity results in all the samples of the study sites were relatively constant depicting the common composition of the rainwater samples and also an equal distribution of these ionic species [9]. The average conductivity of the rainwater samples in all the sites fall between $46.95 \pm 1.44$ to $48.23 \pm 0.65 \mu \mathrm{Scm}^{-1}$, which are very low compared to WHO standard of 400 $\mu \mathrm{Scm}^{-1}$ but in substantial agreement with that reported in other recent works [24 - 27]. These results are probably due to cations contributions [1], [2], [28]. It also predicts the soft nature of the rainwater samples, as Jos Areas is not heavily industrialized. However result round the Industrial areas/Abattoir show a high value in total hardness, indicating the effect of these anthropogenic activities. On a general note each of the sites has a seemingly constant average parameter. However with the first rain in each site, the conductivity was high and this decreases as the rainstorm continues with time. This trend may be due to the atmospheric washout processes. Also the constant conductivity trend could be explained in terms of the relatively constant $\mathrm{pH}$ of the rainwater samples from the sites. Researchers have shown that the solubility of these aerosols and particulate matter are $\mathrm{pH}$ dependent [6], [7]. The solubility increases as the $\mathrm{pH}$ values decrease (increased acidity). The solids and turbidity are relatively constant in all the sites except Industrial Areas /Abattoir and Apata. This could be explained in terms of the industrial activities as well as the dense human activities at such sites. However the mean turbidity and total solids in all the study sites were below the WHO standard [18].

\section{Chemical Parameters Ph, Total Acidity, Hardness}

The $\mathrm{pH}$ of the rainfall samples is generally on the acidic side having an average range between $6.3 \pm$ 0.33 and $6.29 \pm 0.56$. This is to say that some samples had their $\mathrm{pH}$ values lower than the WHO standard of $6.50-8.50$ [18]. This was observed in all the sites, and it could be attributed to the homogenous nature of the atmosphere due to wind and some other factors causing even distribution of the acid causing gaseous compounds like $\mathrm{SO}_{2}, \mathrm{NO}_{2}$ [29]. The low $\mathrm{pH}$ (high acidity) could also be explained to be due to lack of sufficient naturalizing salt or compounds like $\mathrm{NH}_{3}$ and $\mathrm{CaCO}_{3}, \mathrm{Na}_{2} \mathrm{CO}_{3}$ from soil dust particles [4]). A plot of $\left[\mathrm{H}^{+}\right]$against rainfall amount $(\mathrm{mm})$ shows that the concentration of hydrogen ion in the rainwater sample decreases with increasing amount of rainfall, with more $\mathrm{H}^{+}$concentration between $15 \mathrm{~mm}$ and $35 \mathrm{~mm}$ rainfall. This is due to dilution effect [9] [22], [11. Acidity of rainwater may impact on the terrestrial and aquatic environment. High acidic rain also damages materials and roofing sheets just as it is the case in some other oil producing States of Nigeria as a result of gas flaring, causing a consequential and rapid corrosion of the roofing sheets [27]. Ammonium ion as found in the study sites ranged between $0.18 \pm 0.17 \mathrm{mg} / \mathrm{L}$ to $0.95 \pm$ $0.61 \mathrm{mg} / \mathrm{L}$. This results show substantial agreement to some recent works where $\mathrm{NH}_{4}{ }^{+}$concentrations of $0-$ $0.1 \mathrm{mg} / \mathrm{L}$ and $0-0.77 \mathrm{mg} / \mathrm{L}$ was reported [24], [25]. High level of concentration was found at Bukuru, Apata and Lamingo sites, while it is minimal at Dadin Kowa. At Industrial Area/Abattoir, the concentration was relatively low compared to the other sites $(0.18 \pm 17)$. This phenomenon could be ascribed to the industrial activities around Industrial Area/Abattoir. There is high concentration of $\mathrm{NO}_{3}{ }^{-}$and $\mathrm{SO}_{4}{ }^{2-}$ at Industrial Area/Abattoir compared to other sites. Also considering the effect of the dilution, the average volume weighted mean (VWM) result showed that the concentration of ammonia was high at Bukuru, Apata and Lamingo indicating high level of anthropogenic activities or human population but not from industrial source (Kapoor, et al 1993; Hiroshi, et al, 1993). The high $\mathrm{NH}_{4}{ }^{+}$concentration at these sites could also be attributed to microbial activities, as a result of the decomposition of wastes dumped around these areas. A recent report of air quality around Nasco Household products in Industrial Area revealed that the concentration of $\mathrm{SO}_{2}$ and $\mathrm{NH}_{3}$ are $0.06 \mathrm{mg} / \mathrm{L}$ and $0.062 \mathrm{mg} / \mathrm{L}$ respectively while it was $0.05 \mathrm{mg} / \mathrm{L}$ for $\mathrm{NO}_{2}$ (Engineering and 
Environmental management studies, 2002). This explains the neutralization reaction that could occur between these gases. A correlation matrix, using SPSS Version 11.00 , showing strong correlation of $99.99 \%$ with $\mathrm{NO}_{3}{ }^{-}$, $\mathrm{NO}_{2}{ }^{-}$and $\mathrm{SO}_{4}{ }^{2-}$, confirms this. This indicates that the atmospheric aerosols exist as either $\left(\mathrm{NH}_{4}\right) \mathrm{NO}_{3}$, $\left(\mathrm{NH}_{4}\right) \mathrm{NO}_{2}$ or $\left(\mathrm{NH}_{4}\right)_{2} \mathrm{SO}_{4}$ due to gas phase reaction below the cloud level [11], [21], [30]. Here it is critical that all but the $\mathrm{NH}_{4}{ }^{+}$concentration at $\mathrm{S}_{2}$ exceed the WHO standard. However, nitrate and nitrite concentrations are lower than the standard, which is $50 \mathrm{mg} / \mathrm{L}$ and $3 \mathrm{mg} / \mathrm{L}$ respectively. Nitrate and nitrite concentrations were relatively high at Bukuru and Lamingo sites compared to other sites. This is demonstrated in their deposition rates [Table III]. These high concentrations could be due to natural and agricultural activities, as these sites do not have heavy industries around them. The correlation matrix indicates that strong correlation exists between $\mathrm{Cl}^{-}, \mathrm{NO}_{3}{ }^{-}$and $\mathrm{NO}_{2}{ }^{-}$. This may probably be due to their similar source or photochemical processes. Also partial correlation found between nitrate and sulphate suggests similar trends in occurrence and abundance, as both are constituents of polluted urban atmospheres. This is also indicated in their deposition rate and significant correlation between $\mathrm{Mg}$ and $\mathrm{NO}_{3}{ }^{-}$and $\mathrm{NO}_{2}{ }^{-}$thus suggesting their contribution from soil dust particles as $\operatorname{Mg}\left(\mathrm{NO}_{3}\right)_{2}$ or $\mathrm{Mg}\left(\mathrm{NO}_{2}\right)_{2}$ [3], [11]. The Scatter plot of concentration versus the precipitation amount of $\mathrm{NH}_{4}{ }^{+}$, $\mathrm{NO}_{3}{ }^{-}, \mathrm{NO}_{2}{ }^{-}$and $\mathrm{SO}_{4}{ }^{2+}$ indicates a decrease in concentration of species with increasing rainfall precipitation as reported by other researchers [3], [9], [11]. This may be attributed to dilution effects as rainfall amount increases. The sulphate and chloride concentration were relatively constant in the study sites except for Industrial Area and Lamingo. This could be due to the industrial and agricultural activities taking place in the respective sites. However; their concentrations were very much lower than the WHO standards of $250 \mathrm{mg} / \mathrm{L}$. They have similar deposition rate, indicating similar trends in occurrence and abundance as both had constituents of a polluted atmosphere from dust particles and other aerosol composition. The plot of concentration versus precipitation amount indicated that the concentration decreased with increased precipitation. Dilution by condensation or nucleation scavenging of mineral dust might be the cause [32]. There is a significant correlation between $\mathrm{Mg}$ and $\mathrm{NO}_{3}{ }^{-}$, Na and $\mathrm{NH}_{4}{ }^{+}$which seems to suggest that $\mathrm{Mg}$ could equally be an integral part of the alkaline dust particles. High level of $\mathrm{SO}_{4}{ }^{2-}$ at Lamingo indicated the major contribution from dust particles as a result of agricultural and construction works. Also, it could be ascribed to the predominantly Northeastern wind direction, which tends to blow the rain composition from industrial sites towards this area as a result of their similarity in geographical plane. The geographical plume, topography and the entire atmospheric processes contribute to a significant variation in elemental composition of the atmospheric aerosols as well [33]. The levels recorded at Industrial Area /Abattoir and Apata sites could be a major contribution from anthropogenic sources of automobile traffic and industrial activities respectively.

Phosphates in rainwater were found to be very low as only one sample in each of the sites (except Industrial/Abattoir Area) was found to contain some level (insignificant) of phosphate ion $(0.023 \mathrm{mg} / \mathrm{L})$. This agrees with the results of some other works [11], [33], [34] where they reported phosphates concentration in rainwater. Among the twelve samples in $\mathrm{S}_{3}$, eight were found to contain phosphate. This may be as a result of industrial and agricultural applications of phosphate and phosphoric compounds. However, the concentration of phosphate in each case is below the WHO standard. Sodium and calcium concentrations in the rainfall samples of these sites are low as compared to WHO standard of $200 \mathrm{mg} / \mathrm{L}$ and $75 \mathrm{mg} / \mathrm{L}$ respectively. However, they were found not to be relatively constant as it is observed to be a little higher in Industrial Area/Abattoir and Apata sites (for $\mathrm{Na}$ ) and Apata and Lamingo (for $\mathrm{Ca}$ ), putting the effect of dilution into consideration. A correlation matrix indicates that $\mathrm{Ca}, \mathrm{K}$ and $\mathrm{Na}$ are significantly correlated and this could be ascribed to similarity in their emission source. Also it indicates that they probably have similar existence in the atmosphere in the form of dust particles [9], [11], [29]. High level of Ca in the body has not been found to have health effect; hence no maximum contamination limit has been established. However a concentration of $75 \mathrm{mg} / \mathrm{L}$ in drinking water is moderate in order to check the wide domestic application of water [18]. Sulphate of calcium and magnesium to a maximum level of $270 \mathrm{mg} / \mathrm{L}$ and $90 \mathrm{mg} / \mathrm{L}$ respectively improve the taste of drinking water [32]. Studies have also shown that high sodium ion may not be too good for patients with heart diseases as this increases the blood pressure [35]. The concentrations of these ions decrease over time due to atmospheric cleaning processes, but their deposition rate may remain relatively constant. A scatter plot of concentration versus precipitation amount showed that the concentration of the species deceases with increasing precipitation, which may be due to dilution processes.

Magnesium level in the rainfall samples in all the sites was generally low and although no maximum contamination level has yet, been established, high level of $\mathrm{Mg}$ can, however, create a problem for people with kidney disease. They may develop toxic reactions to high level of magnesium including muscle weakness, coma, hypertension and confusion [35] and thus a maximum contamination limit (MCL) of $50 \mathrm{mg} / \mathrm{L}$ is suggested [29]. A concentration level of copper in drinking water of $1 \mathrm{mg} / \mathrm{L}$ is given by WHO as guideline value. It was observed here that the concentration of copper could reach as high as $0.782 \mathrm{mg} / \mathrm{L}$ in rainwater. 
These values are relatively high if it could be a contribution in rainwater only. Copper may be said to exist as $\mathrm{Cu}\left(\mathrm{NO}_{3}\right)_{2}$ and may have the same source with potassium and sodium due to their significant correlation. It could therefore be deduced from these findings that the source of copper in the atmosphere is anthropologic, resulting from mining and industrial activities in the study areas. Its concentration decreased with increased precipitation as shown in the scatter plot of $\mathrm{Cu}$ concentration in rain water.

\section{Conclusions}

It is evident from this study that the atmosphere within Jos and Bukuru metropolis is threatened by pollutants such as $\mathrm{NH}_{3}, \mathrm{NOx}, \mathrm{SO}_{2}, \mathrm{Cu}$; and if not checked from the point sources the concentrations of these pollutants may exceed the international standard within the shortest time possible. This is particularly so for $\mathrm{NH}_{4}{ }^{+}$and $\mathrm{pH}$ values, which are off the tolerance range or limit, and is a thread to the natural ecosystem. This finding advocates for non consumption of rainwater by residents around Industrial Area and highly populated areas as the presence of ionic species beyond the recommended WHO levels pose a serious potential health hazards when consumed. The concentration of rainfall water within the study sites showed that the atmosphere is being polluted to a level that some chemical parameters (ammonium), and $\mathrm{pH}$ exceed the internationally established guideline values. The atmospheric pollution is ascribed to probable source of elements enriched in the areas from refuse incineration, emission from car exhaust, industrial generating plants and natural activities like the microbial decomposition of refuse dumps. These processes enrich the atmosphere with pollutants that consequently get dissolved into the rainwater samples. Generally, low rainfall results in high concentrations; whereas heavy rains result in more dilute samples. In addition, initial stages of rainfall exhibit higher concentration than later stages owing to the initial washout of dust and gases in the atmosphere below cloud base. The lower concentration associated with later stages of rainstorms are generally considered to reflect cloud water concentrations as they result primarily from rainout.

\section{References}

[1] FAITH W L \& Arthur A. Atkission, Jr. (1972) Air pollution. $2^{\text {nd }}$ ed. London: Willey inter science pp 1-27:59, $100243-257$.

[2] LESLIE B; Jakie K; Adam G; David S; Pete K; and Matt W; The effect of rainfall on the pollution and Mineral content of the western Duck pond; U S EPA Publication; pp 1-14 1999

[3] KAPOOR R K ; Wari S.T; Ali K; and sing G (1993) chemical Analysis of fog water at Delhi, North India; J. Atmos. Environment 27A pp 2453-2455 [1993].

[4] HIROSHI S., Isaac R Kaplan, Lloyd S. Shepard (1993); Measurement of $\mathrm{H}_{2} \mathrm{O}_{2}$, Aldehyde and Organic Acids in Los Angels Rainwater: There sources and Deposition rates; J. Atmos. Environment, 27B pp 203-217.

[5] LOSNO R; Bergametti G et carlier P (1992); Origin of the atmospheric particulate matter over North sea and the Atlantic Ocean; J. Atmos. Chem., 15 pp 333-352

[6] DESBOEUFS K V, Losno R Vimeux F and Cholbi S. (1999): The pH dependent dissolution of wind-transported Saharan dust J. Geophys. Res; 104 PP 21287-21299.

[7] DESBOEUFS K V, Losno R. and Colin J.L (2001): Factors influencing aerosol solubility during cloud process: J. Atmos. Environment; 35 pp 3529-3537

[8] LOSNO R; COLIN J L; Le Bris N; Bergametti G; Jickells T et Lim B; (1993): Aluminium solubility in rainwater and molten snow; J. Atmos. Environ. 17. pp 29-43.

[9] RODAJEVIC M and BASHKIN V N. 1999 Practical Environmental analysis Royal Society of Chemistry, Cambridge, U.K. pp 50, 53, $58-165,175-179$

[10] HOWARD A STOBELL (1973): chemical Instrumentation, $2^{\text {nd }}$ edition, Addison Wesley publishing company, Canada: pp $390-408$.

[11] SINGER A.; Shamay Y and Fried M. (1993): Acid rain on mount Carmel Israel J. Atmos. Environment 27A pp 2287-2293.

[12] BALASUBRAMANIAN R. (2002): Characterization of biomass burning in Southeast Asia; Environment Canada, pp1-13.

[13] LLUIS Camarero and Jordi Catalan (199): chemistry of bulkprecipitation in the central and Eastern Pyrenees, Northeastern Spain J. Atmospheric Environment 27A; pp 83-93.

[14] DESPINS Christopher, Khosrow Farahbakhsh and Chantalle Leidl (2009). Assessment of Rainwater Quality from Rainwater Harvesting Systems in Ontario, Canada; Journal of Water Supply, Research and Technology - AQUA 58.2

[15] DVORAK, ET AL (1971): Flame photometry; Laboratory Practice, pp 213-214; 244-245; Iliffe books, London.

[16] APHA 1984: Standard methods for the examination of water and wastewater, $6^{\text {th }}$ Edition: pp 95-98, 133-139, 287-326, 374-39,437450, 467-468; APHA, AWWA. WPCF.

[17] ADEMOROTI C M A (1996): Standard Methods for Water and Effluent Analysis; pp 22-23; 28-43; 55-88; 111-113. ISBN -978-333 99-9-1 Foludex press Ltd. Ibadan.

[20] COLEMAN Richard (1978): Statistics - basic techniques for solving applied problems; Addison Wesley, $3^{\text {rd }}$ Edition pp $133-166$.

[21] TSITOURIDOU R and Samara C: (1993): First Results of Acidic and alkaline constituents determination in Air particulates of Thessalonica, Greece: J. atmospheric environment. 27B pp 313-319

[22] JEAN-MICHAEL Giovannoni (1993): modeling of $\mathrm{SO}_{2}, \mathrm{~Pb}, \& \mathrm{Cd}$ atmospheric deposition over a one year period: J. Atmospheric Environment 27A, pp 1793-1806

[23] KOUTSENOGH P.K. et al (1993): Ion composition of atmospheric aerosol near lake Baikal; J. Atmospheric eamount vol. 27A pp 1629-1632.

[24] RADAIDEH Jamal, Al-Zboon Kamel, Al-Harahsheh Adnan and Al-Adamat Rida (2009): Quality Assessment of Harvested Rainwater for Domestic Use: Jordal Journal of Earth and Environmental Sciences 2 (1) 26 - 31.

[25] SEAN O’hogain, Liam McCarton, Niamh McIntyre, Jenny Pender and Anna Reid; "Physocochemical and Microbilogical Quality of Water from a pilot domestic Rainwater harvesting facility in Ireland” Water and Environment Journal, Vol. 25 Issue 4, Dec. 2011.4 , pp $494-498$. 
[26] KUS, B; Kandasamy, J.; Vigneswararan, S.; Shon, H. K (2011) Water quality in Rainwater Tanks in Rural and Metropolitan Areas of New South Wales, Australia. Journal of Water Sustainability vol. 1, Issue 1. Pp $33-43$.

[27] OLUWOYO D. N. (2011). Physicochemical characteristics of Rainwater Quality of Warri axis of Delta State in Western Niger Delta Region of Nigeria. Journal of Environmental Chemistry and Toxicology 3 (12), pp $320-322$.

[28] CHARLES G. Gebelein (1997): Chemistry and our world: W.M.C. Browa Publishers pp 203-204; 499-500

[29] WHO 1996 Guidelines for drinking water quality, $2^{\text {nd }}$ Ed. Vol.2 Health criteria and other supporting information, Geneva; World Health organization, pp 201-206.

[30] TRIPATHI R M, Ashawa S.C and Khandekar RN (1993): Atmospheric Deposition of Pb, Cd, Cu and Zn in Bombey, India: J. Atmos. Environment 27B, Pp269-273.

[31] WHO (1998) Guidelines for drinking water quality, $2^{\text {nd }}$ Edition. Addendum to vol.1 Recommendations: Geneva, world Health organization pp 6-10.

[32] ELIEZER Ganor, Zev Levin and Doran Pardess (1993): Determining the acidity and chemical composition of fog, haze and cloud droplets in Israel; J. Atmospheric Environment 27A pp 1821-1832.

[33] BERGAMETTI G. Dutot A.L; Buat-Menard P; Losno R and Remouldaki E. (1989) "Seasonal variability of the elemental composition of atmospheric aerosol particles over the Northwestern Mediterranean; Tellus 41 B, pp 353-361.

[34] BERGAMETTI G; Remoudaki E; Losno R; Steiner E; Chatenet B. et Buat-Menard P. (1992) Source, transport and deposition of atmospheric phosphorus over the northwestern Mediterranean. J. Atmos. Chem. 14 pp 501-513.

[35] DOROTA Z. Haman and Del B. Bottcher (1986); Home water quality and safety; Cooperative Extension Service, Institute of Food and Agricultural Sciences, University of Florida Gaines Ville FL 32611 